Phenolic content and antioxidant capacity of istrian olive leaf infusions

Sadržaj fenola i antioksidacijski kapacitet u infuzijama listova istarskih sorata maslina

Kovačić, I., Bilić, J., Dudaš, S., Poljuha, D.

Poljoprivreda/Agriculture

ISSN: 1848-8080 (Online)

ISSN: 1330-7142 (Print)

http://dx.doi.org/10.18047/poljo.23.2.6

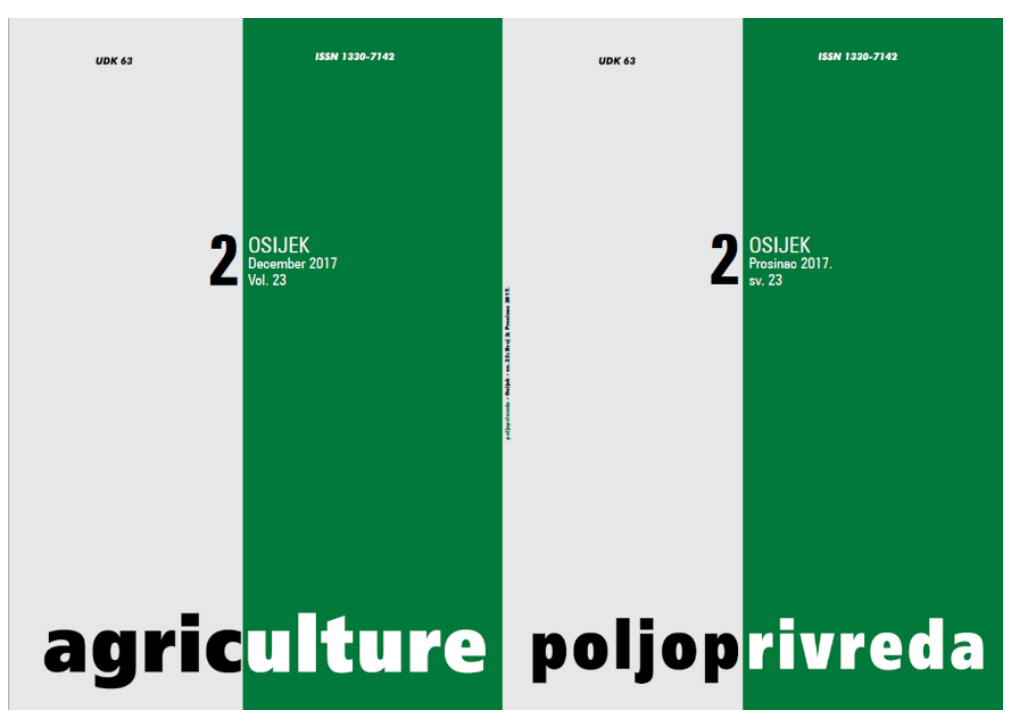

Poljoprivredni fakultet u Osijeku, Poljoprivredni institut Osijek

Faculty of Agriculture in Osijek, Agricultural Institute Osijek 
ISSN $1330-7142$

UDK: 634.63:678.01'048

DOI: $10.18047 /$ poljo.23.2.6

\section{PHENOLIC CONTENT AND ANTIOXIDANT CAPACITY OF ISTRIAN OLIVE LEAF INFUSIONS}

Kovačić, I.(1), Bilić, J.(2), Dudaš, S.(3), Poljuha, D. ${ }^{(4)}$

Original scientific paper

Izvorni znanstveni članak

\section{SUMMARY}

The influence of commonly used steeping times and leaf size on the phenolic content and antioxidant capacity of olive leaf infusions from three Istrian olive cultivars (Buža, Rosinjola and Istarska Bjelica) were studied. Infusions were prepared from whole, rough or finely ground olive leaves immersed in boiled water for 5,15 , or 30 minutes. Extraction efficiency was quantified in terms of the total phenolic, flavonoid, non-flavonoid contents and antioxidant capacity. The phenolic content was primarily affected by infusion time, followed by particle size. The highest total values of phenolic and non-flavonoids were determined in finely ground leaf infusions from cultivars Rosinjola and Buža, while the highest total flavonoids value was detected in Istarska Bjelica after 30 minutes infusion. Particle size provided the highest effect on antioxidant capacity in all cultivars, exhibiting higher values in finely ground leaf infusions. The Rosinjola and I. Bjelica infusions exhibited the highest antioxidant capacity according to ABTS and FRAP assay, respectively. Antioxidant capacity in investigated olive infusions was correlated to TP and TNF, while TF had poor or no effect except in Rosinjola infusions. The results indicate that olive leaves infusion from three Istrian olive cultivars could be a valuable supplement to a daily intake of bioactive compounds.

Key-words: antioxidant capacity, olive leaf infusions, phenolic content

\section{INTRODUCTION}

More than 8 million ha of olive trees are cultivated worldwide, especially in the Mediterranean basin. In Croatian Istria, the local variety Buža dominates the old plantations, followed by Istarska Bjelica, Rosinjola, Črnica and others (Milotić et al., 2005). The area under olive groves in Istria is $5000 \mathrm{ha}$, and the number of fruit trees is estimated at 1,070,000 (Sladonja and Poljuha, 2015) with approximately 5000 oven dry ton (odt) of dry residues from the pruning of olive groves annually.

Olive leaf infusions have been reported to have antibacterial, antifungal and antiviral properties (Korukluoglu et al., 2006; Hayes et al., 2011; Ahmed et al., 2014). They have been used as a remedy against various diseases associated with a reduced risk for cardiovascular disease and certain types of cancers (Trichopoulou et al., 2000). In the past decade, antioxidants and antioxi- dant capacity of olive leaf extracts have been of great interest to the health and food science researchers (Silva et al., 2006; Abaza et al., 2011; Rafiee et al., 2012; Lafka et al., 2013; Goldsmith et al., 2014).

Olive leaves contain biologically active substances with good antioxidant potential (Hayes et al., 2011; Erel et al., 2013). Antioxidant capacity of olive leaf infusions has been positively linked with the phenolics (Abaza et al., 2011; Generalić Mekinić et al., 2014). The main classes of phenolic content present in olives leaves are phenyl ethyl alcohols, simple phenols, flavo-

(1) Ph.D. Ines Kovačić - Department for Natural and Health Sciences, Juraj Dobrila University of Pula, Zagrebačka 30,52100 Pula, Croatia (ikovacic@ unipu.hr), (2) Josipa Bilić - Materials Research Centre, Zagrebačka 30 52100 Pula, Croatia, (3) Ph.D. Slavica Dudaš - Agricultural Department Poreč, Polytechnic of Rijeka, Karla Huguesa 6, 52440 Poreč, Croatia, (4) Ph.D. Danijela Poljuha - Institute of Agriculture and Tourism, Karla Huguesa 8, 52440 Poreč, Croatia 
noids and flavonoid-like compounds (Lee et al., 2009; Hayes et al., 2011; Brahmi et al., 2014). A number of methods have been proposed for the extraction of phenolic content from olive leaves, including the use of advanced technologies, such as microwave, pressurized liquid extraction and ultra-sonic extraction methods (Rafiee et al., 2012). There is a need for the development of "green" extraction procedures, suitable also for household conditions. Whereas tea and herbal infusions are generally prepared by steeping the leaves and herbal parts in hot water, a more comprehensive and thorough survey of the composition of herbal infusion is necessary (Komes et al., 2011). Water as a cheap, non-hazardous polar solvent, showed effectiveness in extraction of a vast array of phenolic compounds with high antioxidant activities from olive leaves (Generalić Mekinić et al., 2014; Goldsmith et al., 2014) and a number of plant materials (Rusak et al., 2008).

The aim of this study was to reveal the potential of Istrian local olive varieties as a natural source of bioactive compounds, especially as a supplement to its daily intake convenient for household preparation. For that purpose, we investigated the phenolic content and antioxidant capacity of olive leaf infusions obtained from Istrian cultivars Rosinjola, Buža and Istarska Bjelica, as well as the impact of the infusion time and the particle size of leaves on the extraction efficiency of bioactive compounds.

\section{MATERIAL AND METHODS}

Olive leaves of Rosinjola, Buža and Istarska Bjelica (I. Bjelica) cultivars were hand-picked from olive trees in Poreč, Istria, Croatia in July 2015. The plant material was dried at room temperature until constant weight. One part of whole (W) leaf samples from three cultivars was stored in the dark until analyses, while part of them were ground using high-speed grinder (Moulinex DJE243) for 5 seconds (Roughly Ground, RG) and for 30 seconds (Finely Ground, FG). The average size of RG olive leaves particles was $3.98 \pm 1.56 \mathrm{~mm}$ measured with light Microscope (Olympus BX51) with associated camera (Olympus XC50), while that of FG leaves was $152.17 \pm 45.60 \mu \mathrm{m}$ measured with a $0.05 \mathrm{~mm}$ precision digital calliper. In order to simulate household infusions preparation conditions, extraction was carried out by pouring $150 \mathrm{~mL}$ of boiled distilled water over the olive leaves samples $(1.5 \mathrm{~g})$ at room temperature. After extraction $(5,15$ or 30 minutes), the infusions were filtered through a Munktell filter paper 21/N (80 g/qm).

Total phenolics (TP) of olive leaf infusions were determined spectrophotometrically according to a modified method of Singleton et al. (1999). To determine the content of total non-flavonoids (TNF) the method of Ough and Amerine (1988) was used. Total flavonoids (TF) were determined using the method of Zhishen et al. (1999). Antioxidant capacity (AC) of extracts was deter- mined by measuring ABTS [2,2'-azino-bis(3-ethylbenzothiazoline-6-sulphonic acid)] and FRAP (2,2-diphenyl2-picrylhydrazyl) radical scavenging activities according to methods of Re et al. (1999) and Benzie and Strain (1996), respectively. Each sample was prepared in two subsamples. All measurements were performed in triplicate.

All data were calculated using the Statistica 6.0 software (StatSoft Inc, Tulsa, Oklahoma, USA). Analysis of variance (factorial ANOVA) followed by a Tukey-HSD (Honest Significant Difference) was used to determine the differences in the phenolic content and antioxidant capacity. The correlation between the contents of bioactive compounds and antioxidative capacity was determined by calculating the Pearson's coefficient at 0.05 level.

\section{RESULTS AND DISCUSSION}

In this study, the infusions of olive leaves from three Istrian cultivars Rosinjola, Buža and Istarska Bjelica were compared. Our investigations were focused on shorter times of extraction (up to $30 \mathrm{~min}$ ) and easy grinding to simulate extraction conditions usually used for preparing tea at home. The effect of different times of infusion $(5,15,30$ minutes) and leaf particle size (W, RG and FG) on phenolic content and antioxidant capacity from olive leaf infusions was detected. TP ranged from $0.45 \pm 0.05$ (Fig. 1A) up to $30.28 \pm 1.37 \mathrm{mg} \mathrm{GAE} / \mathrm{g} \mathrm{DM}$ (Fig. 1C) depending on the infusion time and particle size. The highest TP was determined after 30 minutes of infusion. Among the tested W (Fig. 1A) and RG (Fig. 1B) leaf infusions, Rosinjola had a significantly higher $(\mathrm{P}<0.05)$ concentration of TP than Buža and Istarska Bjelica both after 15 and 30 minutes of infusion. The only exception was found in FG leaves where Buža infusions showed higher TP when compared to Rosinjola and Istarska Bjelica (Fig. 1C), in concordance with the results of Mujić et al. (2011). Goldsmith et al. (2014) detected $32.45 \mathrm{mg} \mathrm{GAE} / \mathrm{g}$ DM of TP in Corregiola olive leaf infusion after 50-70 minutes of extraction. We obtained the same results after 30 minutes of incubation in FG olive leaf infusion from all cultivars. TP content in Olea europaea leaves in Anatolia extracted with methanol by homogeniser-assisted extraction and ultrasound-assisted methods ranged from 10.11 to $61.66 \mathrm{mg}-\mathrm{GAE} / \mathrm{g}$ DM (Bilgin and Şahin, 2013). The variation found in the olive leaves infusions tract reported in the previous study could be due to different methods applied for extraction and also the influence of the sample origin (Salah, 2012). The obtained data correspond to the results of a study carried out on Istrian cultivars (Poljuha et al., 2008) that revealed statistically significant differences in total phenolic mass fraction and antioxidant activity of olive oil among Rosinjola, Buža and Istarska Bjelica, where Rosinjola emerged as a cultivar with the highest measured TP and AC content. 


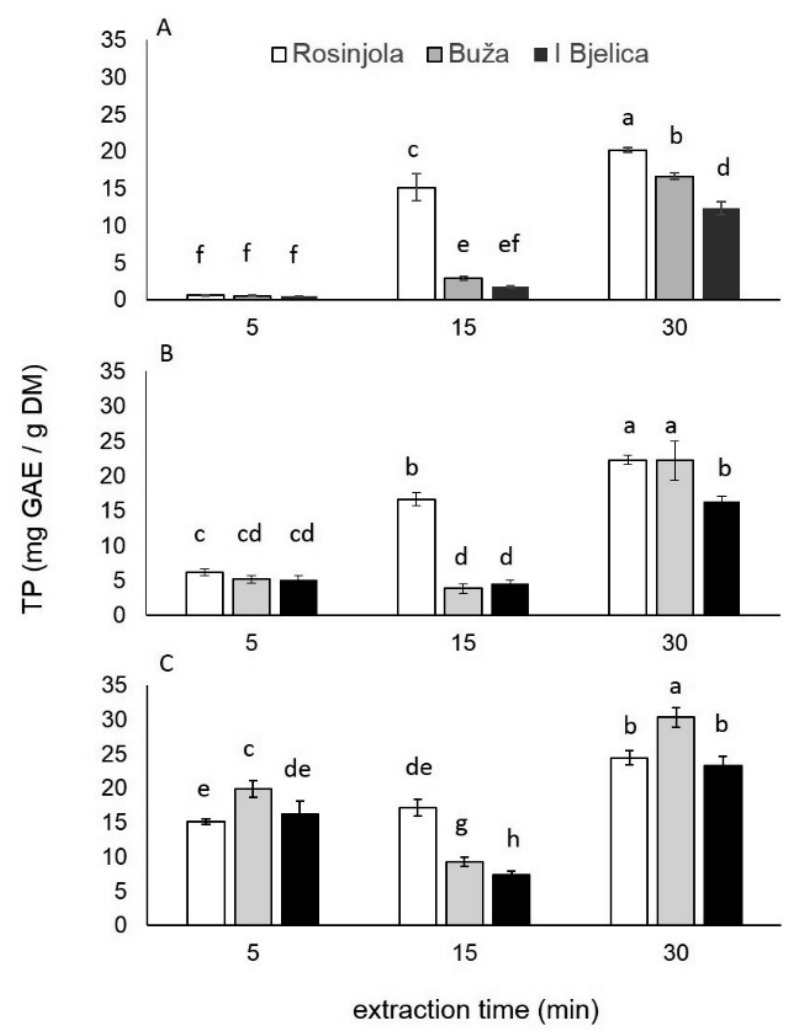

Figure 1. Total phenols (mean $\pm S D$ ) in infusions of whole (A), roughly (B) and finely ground (C) Rosinjola, Buža and Istarska Bjelica (I. Bjelica) leaves after 5, 15 and 30 min of extraction. The means labelled by different letters are significantly different (Two-way ANOVA, Tukey's test, $\mathbf{P}<\mathbf{0 . 0 5})$

Slika 1. Ukupni fenoli (srednja vrijednost $\pm S D$ ) u infuzijama cjelovitih (A), grubo (B) i fino mljevenih (C) listova Rosinjole, Buže i Istarske Bjelice (I. Bjelice) nakon 5, 15 i 30 min ekstrakcije. Mala slova označavaju značajne razlike među vrijednostima (Dvosmjerna ANOVA, Tukey's test, $P<0,05)$

Depending on the time of the extraction and particle size, TNF ranged from $0.13 \pm 0.04$ (Fig. $2 \mathrm{~A}$ ) up to $18.90 \pm 1.03 \mathrm{mg} \mathrm{GAE} / \mathrm{g}$ DM (Fig. 2C). The highest TNF content was determined after 30 minutes of infusion. Significantly higher $(\mathrm{P}<0.05)$ TNF content in W leaf infusion was determined from Rosinjola and Buža after 30 minutes of extraction in comparison to Istarska Bjelica (Fig. 2A). In RG leaf infusions, the highest TNF content was measured after 30 minutes of extraction in all cultivars without significant difference (Fig 2B). The significantly highest $(\mathrm{P}<0.05)$ TNF content in Buža, in comparison to Rosinjola and Istarska Bjelica, was detected after 30 minutes of infusions from FG olive leaves (Fig. 2C).

Depending on the time of extraction and particle size, TF ranged from $0.15 \pm 0.02$ (Fig. $3 \mathrm{~A}$ ) up to $30.34 \pm 3.65 \mathrm{mg} \mathrm{CE} / \mathrm{g}$ DM (Fig. $3 \mathrm{C}$ ). The highest TF content was detected in Istarska Bjelica $W$ and $R G$ infusions already after 15 minutes of infusion, keeping it highest also after 30 minutes. In FG leaf infusions, Istarska Bjelica exhibited the highest TF content, followed by Buža (Fig. 3C). The lower TF content was determined in all Rosinjola infusions. Our results showed that olive leaf infusions from Istrian cultivars had higher TF content than Chétoui infusion, which contained $6.23 \pm 0.62 \mathrm{mg} \mathrm{CE} / \mathrm{g} \mathrm{DM}$ after $24 \mathrm{~h}$ extraction (Abaza et al., 2011). These differences may be due to genetic factors, different environmental conditions, stage of maturity, growth stage, soil fertilization and the part of the plant used, amongst other factors that affect quantitative variation in these phytochemicals (Dragović-Uzelac et al., 2009).

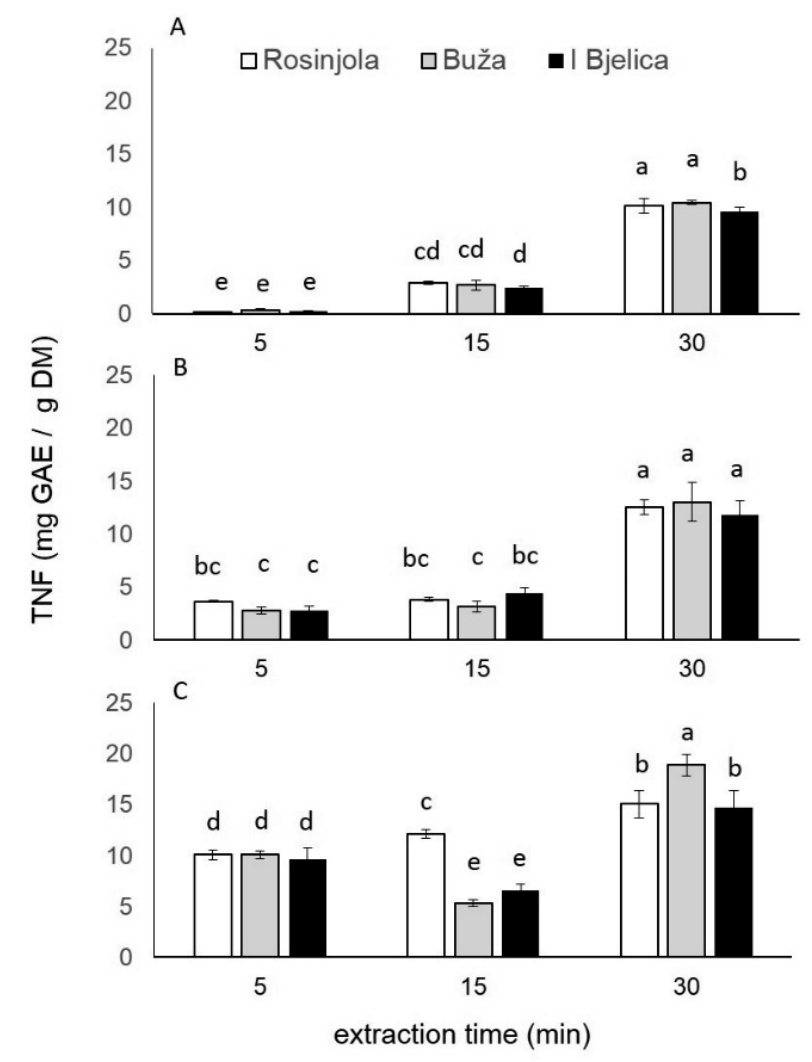

Figure 2. Total non-flavonoids (mean $\pm S D$ ) in infusions of whole $(A)$, roughly $(B)$ and finely (C) ground Rosinjola, Buža and Istarska Bjelica (I. Bjelica) leaves after 5, 15 and $30 \mathrm{~min}$ of extraction. The means labelled by different letters are significantly different (Two-way ANOVA, Tukey's test, $\mathrm{P}<\mathbf{0 . 0 5}$ )

Slika 2. Ukupni neflavonoidi (srednja vrijednost $\pm S D$ ) u infuzijama cjelovitih $(A)$, grubo $(B)$ i fino mljevenih (C) listova Rosinjole, Buže i Istarske Bjelice (I. Bjelice) nakon 5, 15 i 30 min ekstrakcije. Mala slova označavaju značajne razlike među vrijednostima (Dvosmjerna ANOVA, Tukey's test, $P<0,05)$ 


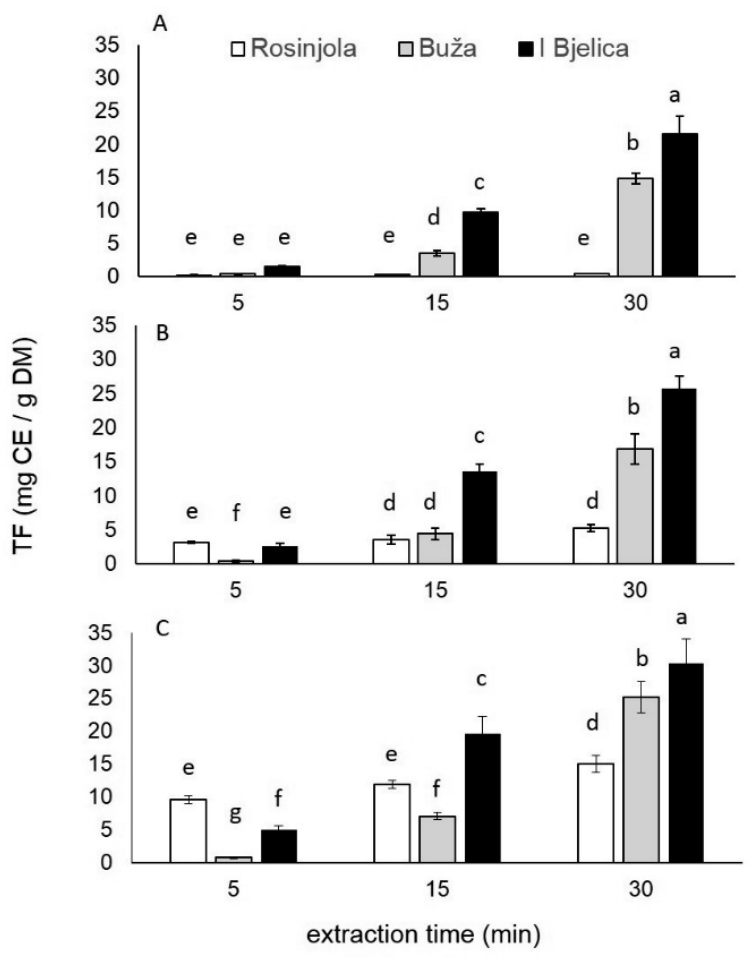

Figure 3. Total flavonoids (mean $\pm S D$ ) in infusions of whole (A), roughly (B) and finely (C) ground Rosinjola, Buža and Istarska Bjelica (I. Bjelica) leaves after 5, 15 and $30 \mathrm{~min}$ of extraction. The means labelled by different letters are significantly different (Two-way ANOVA, Tukey's test, $\mathbf{P}<0.05)$

Slika 3. Ukupni flavonoidi (srednja vrijednost $\pm S D$ ) u infuzijama cjelovitih $(A)$, grubo $(B)$ i fino mljevenih (C) listova Rosinjole, Buže i Istarske Bjelice (I. Bjelice) nakon 5, 15 i 30 min ekstrakcije. Mala slova označavaju značajne razlike među vrijednostima (Dvosmjerna ANOVA, Tukey's test, $P<0,05)$

The factorial analysis showed that infusion time had the highest effect on TP and TNF content of olive leaf infusions from Istrian cultivars, followed by the effects of particle size and cultivar (Table 1). Our results confirmed the ones from previous studies of phenolic content in plant extracts, which correlates with extraction time and reaches its maximum after 30 minutes of extraction (Cheong et al., 2005; Rusak et al., 2008). With regard to olive cultivars (Abaza et al., 2011; Goldsmith et al., 2014), no longer extraction period for the preparation of infusions should be recommended for Istrian cultivars. Literature data confirm this presumption for infusion time, although there are no data on effects of different particle size on phenolic content from olive leaf infusions. Moreover, extraction efficiency of phenolic content is cultivar specific in our study, particularly TF (Table 1) and highly dependent on the infusion time and particle size. Influence of the particle size on increasing extraction efficiency of tea leaves was also determined (Kopjar et al., 2015). These results also indicate that grinding of tea leaves increased the concentration of phenolic content and consequently affected the free radical scavenging ability.

$A C$ of olive leaves infusions from Istrian cultivars (measured by both ABTS and FRAP assays) was affected by particle size, followed by extraction time and cultivar in infusions obtained (Table 1). AC determined by the ABTS assay showed that Rosinjola infusions obtained by W, RG and FG (Fig. 4) olive leaves exhibit higher $\mathrm{AC}$ values in comparison to those of the infusions from Buža and Istarska Bjelica independently of extraction time. Infusions from Rosinjola and Buža leaves came out at the end of the scale of the detection after 30 minute extraction ( $>50 \mathrm{mM} \mathrm{TE} / \mathrm{g} \mathrm{DM}$ ), while Istarska Bjelica corresponded with $48.46 \mathrm{mM} \mathrm{TE} / \mathrm{g} \mathrm{DM}$, which is higher than reported in Chétoui infusion $(0.629 \mathrm{mM}$ TE/g DM) after 24h extraction (Abaza et al., 2011). Olive leaf infusions showed good levels of $A C$ when compared with Ginkgo biloba, a well-known phytochemical source of antioxidants, which displayed values of $0.312 \mathrm{mM}$ $\mathrm{TE} / \mathrm{g}$ DM (Tawaha et al., 2007). Results of FRAP assay (Fig. 4) showed that WL infusions exhibited the lowest antioxidant capacity and this effect was not increased by prolongation of extraction time (Fig. 4).

Table 1. Factorial ANOVA results testing the influence of cultivar, infusion time and particle size on total phenolic (TP, GAE/g DM), total non-flavonoids TNF (GAE/g DM), total flavonoids TF (CE/g DM) content and antioxidant capacity measured by ABTS (mM TE/g DM) and FRAP (mM Fe(II)/g DM) assays

Tablica 1. Utjecaj sorte, vremena infuzije i veličine čestica na ukupne fenole (TP, GAE/g DM), ukupne neflavonoide TNF (GAE/g DM), ukupne flavonoide TF (CE/g DM) i antioksidativni kapacitet mjeren metodama ABTS (mM TE/g DM) i FRAP (mM Fe(II)/g DM)

\begin{tabular}{|l|c|c|c|c|c|c|c|}
\hline & \multicolumn{9}{|c|}{ Mean Squares $\left(\mathrm{s}^{2}\right)$} \\
\hline Source of variation & $\mathrm{df}$ & TP & TNF & TF & $\mathrm{df}$ & ABTS & FRAP \\
\hline Cultivar & 2 & $576.21^{\mathrm{a}}$ & $15.64^{\mathrm{a}}$ & $1846.27^{\mathrm{a}}$ & 2 & - & $45.91^{\mathrm{a}}$ \\
\hline Particle size & 2 & $2212.28^{\mathrm{a}}$ & $1100.73^{\mathrm{a}}$ & $1452.34^{\mathrm{a}}$ & 1 & $628.60^{\mathrm{a}}$ & $3551.89^{\mathrm{a}}$ \\
\hline Infusion time & 2 & $4966.75^{\mathrm{a}}$ & $2184.52^{\mathrm{a}}$ & $4473.23^{\mathrm{a}}$ & 1 & $197.30^{\mathrm{a}}$ & $135.57^{\mathrm{a}}$ \\
\hline
\end{tabular}

$\mathrm{aP}<0.05, \mathrm{df}=$ degree of freedom 

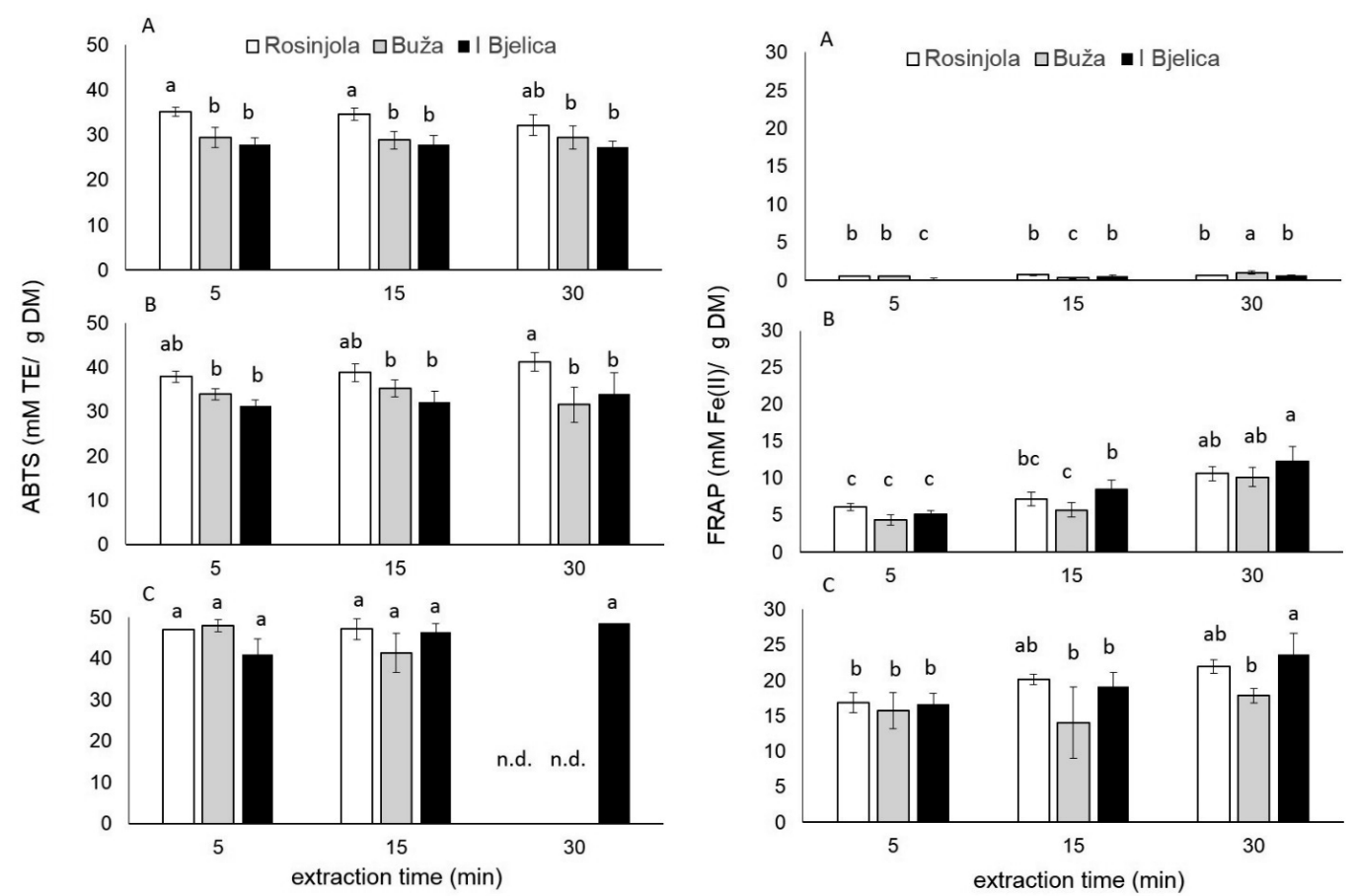

Figure 4. Antioxidant capacity (mean \pm SD) of infusions from whole (A), roughly (B) and finely (C) ground Rosinjola, Buža and Istarska Bjelica (I. Bjelica) leaves after 5, 15 and 30 min of extraction measured by ABTS assay and FRAP assay. The means labelled by different letters are significantly different (Two-way ANOVA, Tukey's test, $\mathbf{P}<0.05$ )

Slika 4. Antioksidativni kapacitet (srednja vrijednost $\pm S D$ ) u infuzijama cjelovitih (A), grubo (B) i fino mljevenih (C) listova Rosinjole, Buže i Istarske Bjelice (I. Bjelice) nakon 5, 15 i 30 min ekstrakcije, mjerenih ABTS i FRAP metodom. Mala slova označavaju značajne razlike među vrijednostima (Dvosmjerna ANOVA, Tukey's test, $P<0,05$ )

The highest $A C$ was measured in Rosinjola and Istarska Bjelica (Fig. 4) FG leaf infusions after 30 minutes of extraction. Moreover, AC from Corregiola olive leaves infusion had much higher FRAP values, up to $91.05 \mathrm{mg} \mathrm{TE} / \mathrm{g}$ DM (Goldsmith et al., 2014). These differences in $A C$ values correspond to differences noted in TP, TNF and TF contents found in Corregiola leaves. Goldsmith et al. (2014) found high relation between TP, TNF and TF contents and AC in studies of wild edible plants and Corregiola olive leaves infusion, respectively. Moreover, Mujić et al. (2011) found that antioxidant activity from Istrian olive leaf extracts was in good correlation with TP. Our study showed a significant correlation between TP $(r<0.50, P<0.05$, Table 2$)$ and TNF $(r=0.50, P<0.05$, Table 2) with antioxidant capacity measured by ABTS. In addition, we noticed a significantly positive correlation between TF $(0.97, \mathrm{P}<0.05$, Table 2) in Rosinjola infusion and antioxidant capacity measured by ABTS. Antioxidant capacity measured by FRAP assay showed significantly positive correlation with TP (0.61, $\mathrm{P}<0.05$, Table 2), TNF $(0.70, \mathrm{P}<0.05$, Table 2$)$ and TF $(0.54, \mathrm{P}<0.05$, Table 2$)$.

Table 2. Correlation matrix between antioxidant capacity (ABTS and FRAP assays) and total phenolic (TP), total non-flavonoids (TNF) and total flavonoids (TF) contents in olive leaf infusions from cultivars Rosinjola, Buža and Istarska Bjelica (I. Bjelica)

Tablica 2. Korelacija između antioksidativnoga kapaciteta (mjerenog ABTS i FRAP metodom) i sadržaja ukupnih fenola, neflavonoida i ukupnih flavonoida u infuzijama lišća Rosinjole, Buže i Istarske Bjelice (I. Bjelice)

\begin{tabular}{|c|c|c|c|c|c|c|c|c|}
\hline Phenolic content & & TP & TNF & TF & & TP & TNF & TF \\
\hline Antioxidant capacity & ABTS & & & & FRAP & & & \\
\hline Cultivar & Rosinjola & 0.23 & 0.57 & $0.97^{\mathrm{a}}$ & & 0.50 & $0.76^{\mathrm{a}}$ & $0.99^{\mathrm{a}}$ \\
\hline Buža & & 0.36 & 0.25 & -0.35 & & $0.73^{\mathrm{a}}$ & $0.68^{a}$ & 0.43 \\
\hline I. Bjelica & & 0.64 & 0.62 & 0.48 & & $0.73^{\mathrm{a}}$ & $0.71^{\mathrm{a}}$ & 0.54 \\
\hline Totally & & $0.49^{a}$ & $0.48^{\mathrm{a}}$ & 0.19 & & $0.61^{\mathrm{a}}$ & $0.70^{a}$ & $0.54^{\mathrm{a}}$ \\
\hline
\end{tabular}

ap $<0.05$ 
Moreover, Rosinjola showed the highest correlation in antioxidant capacity measured by FRAP assay and TNF $(0.76, \mathrm{P}<0.05$, Table 2$)$ and TF $(0.99, \mathrm{P}<0.05$, Table 2). It is evident that the antioxidant capacity in investigated olive infusions was linked to TP and TNF, while TF had poor or no effect as was found in study of fruits (Barreira et al., 2008). The results of Rafiee et al. (2012) study on the olive leaves revealed that phenolic content is likely to contribute from 49 to $97 \%$ of the antioxidant capacity. It implies that antioxidant activity of plant extracts is not restricted to phenolic content, which could be supported by our study. Other such secondary antioxidant metabolites, such as phytosterols, tocopherols, carotenoids, chlorophyll and vitamins, may also contribute to total antioxidant activity (Ghanbari et al., 2012). However, Mujić et al. (2011) found that the flavonoids, luteolin, apigenin and diosmetin are the main phenolic compounds in extracts of Istrian olive leaves. Thus, they could be used as easily accessible, natural antioxidants in the diet and treatment of pathophysiological conditions related to oxidative stress.

\section{CONCLUSION}

In conclusion, our results further support the view that olive leaf infusions from three Istrian cultivars are promising sources of natural antioxidants. Phenolic content and antioxidant capacities differ among three selected olive cultivars. Among the olive leaf infusions, those from Rosinjola and Buža exhibited the highest TP and TNF content, while Istarska Bjelica was characterized by the highest content of TF. The optimal conditions for the aqueous extraction of phenolic content from olive leaves were proposed to be at 30 minutes and finely ground leaves. A significant correlation between total phenolic and non-flavonoids content and $\mathrm{AC}$ values in olive leaf infusions showed in this study indicated their contribution to the antioxidant capacity. Using olive leaves as a starting material for the extraction of phenolic compounds via this simple and inexpensive method constitutes a viable use for this agricultural waste product and may potentially serve as an additional source of income for olive growers/olive oil producers.

\section{ACKNOWLEDGEMENT}

The Croatian Ministry of Science, Education and Sport financially supported this study. The authors are grateful to student Marina Čović for assistance with laboratory work.

\section{REFERENCES}

1. Abaza, L., Ben Youssef, N., Manai, H., Mahjoub Haddada, F., Methenni K., Zarrouk, M. (2011): Chétoui olive leaf extracts: influence of the solvent type on phenolics and antioxidant activities. Grasas y aceites, 62: 96-104.

2. Ahmed, A.M., Rabii, N.S., Garbaj, A.M., Abolghait, S.K. (2014): Antibacterial effect of olive (Olea europaea L.) leaves extract in raw peeled undeveined shrimp (Penaeus semisulcatus). International Journal of Veterinary Science and Medicine, 2: 53-56.

doi: http://dx.doi.org/10.1016/j.jjvsm.2014.04.002

3. Barreira, J.C.M., Ferreira, I.C.F.R., Oliveira, M.B.P.P., Pereira, J.A. (2008): Antioxidant activities of the extracts from chestnut flower, leaf, skins and fruit. Food Chemistry, 107: 1106-1113.

doi: http://dx.doi.org/10.1016/j.foodchem.2007.09.030

4. Benzie, I.F., Strain, J.J. (1996): The ferric reducing ability of plasma (FRAP) as a measure of "antioxidant power": the FRAP assay. Analytical Biochemistry, 239: 70-76.

doi: http://dx.doi.org/10.1006/abio.1996.0292

5. Bilgin, M., Şahin, S. (2013): Effects of geographical origin and extraction methods on total phenolic yield of olive tree (Olea europaea) leaves. Journal of the Taiwan Institute of Chemical Engineers, 44: 8-12.

doi: http://dx.doi.org/10.1016/j.jtice.2012.08.008

6. Brahmi F., Mechri B., Dhibi M., Hammami, M. (2014): Variation in antioxidant activity and phenolic content in different organs of two Tunisian cultivars of Olea europaea L. Acta Physiologiae Plantarum, 36: 169-178. doi: http://dx.doi.org/10.1007/s11738-013-1397-4

7. Cheong, W.J., Park, M.H., Kang, G.W., Ko, J.H., Seo, Y.J. (2005): Determination of catechin compounds in Korean green tea Infusions under various extraction conditions by high performance liquid chromatography. Bulletin of the Korean Chemical Society, 26: 747-754.

8. Dragović-Uzelac, V., Bursać Kovačević, D., Levaj, B., Pedisić, S., Mezak, M., Tomljenović, A. (2009): Polyphenols and antioxidant capacity in fruits and vegetables common in the Croatian diet. Agriculturae Conspectus Scientificus, 74: 175-179.

9. Erel, R., Yermiyahu, U., Van Opstal, J., Ben-Gal, A., Schwartz, A., Dag, A. (2013): The importance of olive (Olea europaea L.) tree nutritional status on its productivity. Scientia Horticulturae, 159: 8-18.

doi: http://dx.doi.org/10.1016/j.scienta.2013.04.036

10. Generalić Mekinić, I., Gotovac, M., Skroza, D., Ljubenkov, I., Burčul, F., Katalinić, V. (2014): Effect of the extraction solvent on the oleuropein content and antioxidant properties of olive leaf (cv. Oblica, Lastovka and Levantinka) extracts. Croatian Journal of Food Science and Technology, 6: 7-14.

11. Ghanbari, R., Anwar, F., Alkharfy, K.M., Gilani, A.H., Saari, N. (2012): Valuable nutrients and functional bioactives in different parts of olive (Olea europaea L.) - A Review. International Journal of Molecular Sciences, 13: 3291-3340.

doi: http://dx.doi.org/10.3390/ijms13033291

12. Goldsmith, C., Vuong, 0., Stathopoulos, C., Roach, P., Scarlett, C. (2014): Optimization of the aqueous extraction of phenolic compounds from olive leaves. Antioxidants, 3: 700-712.

doi: http://dx.doi.org/10.3390/antiox3040700

13. Hayes, J.E., Allen, P., Brunton, N., O'Grady, M.N., Kerry, J.P. (2011): Phenolic composition and in vitro antioxidant capacity of four commercial phytochemical products: Olive leaf extract (Olea europaea L.), lutein, sesamol and ellagic acid. Food Chemistry, 126: 948-955. 
doi: http://dx.doi.org/10.1016/j.foodchem.2010.11.092

14. Komes, D., Belščak-Cvitanović, A., Horžić, D., Marković, K., Kovačević Ganić, K. (2011): Characterisation of pigments and antioxidant properties of three medicinal plants dried under different drying conditions. Proceedings of the $11^{\text {th }}$ International Congress Engineering and Food, 22-26 May 2011, Athens, Greece, pp. 22-26.

15. Kopjar, M., Tadić, M., Piližota, V. (2015): Phenol content and antioxidant activity of green, yellow and black tea leaves. Chemical and Biological Technologies in Agriculture, 2: 1-6.

doi: http://dx.doi.org/10.1186/s40538-014-0028-7

16. Korukluoglu, M., Sahan, Y., Yigit, A., Karakas, R. (2006): Antifungal activity of olive leaf (Olea europaea L.) extracts from the Trilye Region of Turkey. Annals of Microbiology, 56: 359-362.

doi: http://dx.doi.org/10.1007/bf03175032

17. Lafka, T.I., Lazou, A., Sinanoglou, V., Lazos, E. (2013): Phenolic extracts from wild olive leaves and their potential as edible oils antioxidants. Foods, 2: 18-31. doi: http://dx.doi.org/10.3390/foods2010018

18. Lee, O.H., Lee, B.Y., Lee, J., Lee, H.B., Son, J.Y., Park, C.S., Shetty, K., Kim, Y.C. (2009): Assessment of phenolicsenriched extract and fractions of olive leaves and their antioxidant activities. Bioresour Technology, 100: 61076113.

doi: http://dx.doi.org/10.1016/j.biortech.2009.06.059

19. Milotić, A., Šetić, E., Peršurić, Đ., Poljuha, D., Sladonja, B., Brščić, K. (2005): Identification and characterization of autohthonus olive varieties in Istria (Croatia). AAnnales: anali za istrske in mediteranske študije. Series historia naturalis, 15: 251-256.

20. Mujić, I., Živković, J., Nikolić, G., Vidović, S., Trutić, N., Kosić, U., Jokić, S., Ruznić, A. (2011): Phenolic compounds in olive leaf extract as a source of useful antioxidants. Hrvatski časopis za prehrambenu tehnologiju, biotehnologiju i nutricionizam, 6: 129-133.

21. Ough, C.S., Amerine, M.A. (1988): Methods for analysis of musts and wine. John Wiley \& Sons, New York.

22. Poljuha, D., Sladonja, B., Šetić, E., Milotić, A., Bandelj D., Jakše J., Javornik B. (2008): DNA fingerprinting of olive varieties in Istria (Croatia) by microsatellite markers. Scientia Horticulturae, 115: 223-230.

doi: http://dx.doi.org/10.1016/j.scienta.2007.08.018
23. Rafiee, Z., Jafari, S.M., Alami, M., Khomeiri, M. (2012): Antioxidant effect of microwave-assisted extracts of olive leaves on sunflower oil. Journal of Agricultural Science and Technology, 14: 1497-1509.

24. Re, R., Pellegrini, N., Proteggente, A., Pannala, A., Yang, M., Rice-Evans, C. (1999): Antioxidant activity applying an improved ABTS radical cation decolorization assay. Free Radical Biology \& Medicine, 26: 1231-1237.

25. Rusak, G., Komes, D., Likić, S., Horžić, D., Kovač, M (2008): Phenolic content and antioxidative capacity of green and white tea extracts depending on extraction conditions and the solvent used. Food Chemistry, 110: 852-858.

doi: http://dx.doi.org/10.1016/j.foodchem.2008.02.072

26. Salah, M.B., Abdelmelek, H, Abderraba, M. (2012): Study of phenolic composition and biological activities assessment of olive leaves from different varieties grown in Tunisia. Medicinal Chemistry, 2: 107-111. doi: http://dx.doi.org/10.4172/2161-0444.1000124

27. Silva, S., Gomes, L., Leitao, F., Coelho, A., Boas, L.V. (2006): Phenolic compounds and antioxidant activity of Olea europaea L. fruits and leaves. Food Science and Technology International, 12: 385-395.

28. Singleton, V.L., Orthofer, R., Lamuela-Raventós, R.M. (1999): Methods in Enzymology. Academic Press, 152 178.

29. Sladonja, B., Poljuha, D. (2015): Characterisation of autochthonous olive varieties in Istria. Institute of Agriculture and Tourism, Poreč.

30. Tawaha, K., Alali, F.0., Gharaibeh, M., Mohammad, M., El-Elimat, T. (2007): Antioxidant activity and total phenolic content of selected Jordanian plant species. Food Chemistry, 104: 1372-1378. doi: http://dx.doi.org/10.1016/j.foodchem.2007.01.064

31. Trichopoulou, A., Lagiou, P., Kuper, H., Trichopoulos, D. (2000): Cancer and Mediterranean dietary traditions. Cancer epidemiology, biomarkers \& prevention: a publication of the American Association for Cancer Research, cosponsored by the American Society of Preventive Oncology, 9: 869-873.

32. Zhishen, J., Mengcheng, T., Jianming, W. (1999): The determination of flavonoid contents in mulberry and their scavenging effects on superoxide radicals. Food Chemistry, 64: 555-559. 


\section{SADRŽAJ FENOLA I ANTIOKSIDACIJSKI KAPACITET U INFUZIJAMA LISTOVA ISTARSKIH SORATA MASLINA}

\section{SAŽETAK}

Proučavani su utjecaji metoda pripreme infuzija $i$ veličine listova na fenolni sadržaj $i$ antioksidacijske sposobnosti infuzija listova tri istarske sorte maslina (Buža, Rosinjola i lstarska bjelica). Infuzije su pripremljene iz cjelovitih, grubo $i$ fino mljevenih listova maslina ekstrahiranih u prokuhanoj vodi 5,15 ili 30 minuta. Učinkovitost je ekstrakcije kvantificirana sadržajem fenola, flavonoida, neflavonoida $i$ antioksidacijskoga kapaciteta. Fenolni sadržaj prvenstveno je utjecao na infuzijsko vrijeme, nakon čega slijedi veličina čestica listova. Najveće vrijednosti ukupnih fenola i neflavonoida izmjerene su u infuzijama fino mljevenih listova sorti Rosinjola i Buža, dok je najveća vrijednost ukupnih flavonoida izmjerena u infuziji listova Istarske bjelice, nakon 30 minuta ekstrakcije. Veličina čestica imala je najveći učinak na antioksidacijski kapacitet u svim sortama, pokazujući veće vrijednosti u infuzijama fino usitnjenih listova. Najveće vrijednosti antioksidacijskoga kapaciteta zabilježene su u infuzijama listova Rosinjole mjerene ABTS metodom, a I. bjelice FRAP metodom. Antioksidacijski kapacitet $u$ ispitivanim infuzijama listova maslina korelira sa sadržajem ukupnih fenola $i$ neflavonoida, dok ukupni flavonoidi imaju slab učinak (osim u infuzijama Rosinjole). Dobiveni rezultati ukazuju na to da infuzije listova istarskih sorata maslina mogu biti vrijedan dodatak dnevnome unosu bioaktivnih spojeva.

Ključne riječi: antioksidacijski kapacitet, infuzije maslinova lišća, fenolni sadržaj

(Received on 24 July 2017; accepted on 19 October 2017 - Primljeno 24. srpnja 2017.; prihvaćeno 19. listopada 2017.) 